\title{
Argélia: \\ colonização e \\ independência
}

0 papel da arquitetura e do urbanismo nos países árabes

\section{ANDREA PICCINI}

\begin{abstract}
À primeira vista, Oran, com efeito, é uma cidade ordinária, simples prefeitura francesa na costa argelina.

Cidade feia, de aspecto sossegado. Com o tempo vemos o que a distingue de tantas outras cidades comerciais, em todas as latitudes.
\end{abstract}

(Albert Camus in A peste. Tradução de Graciliano Ramos)

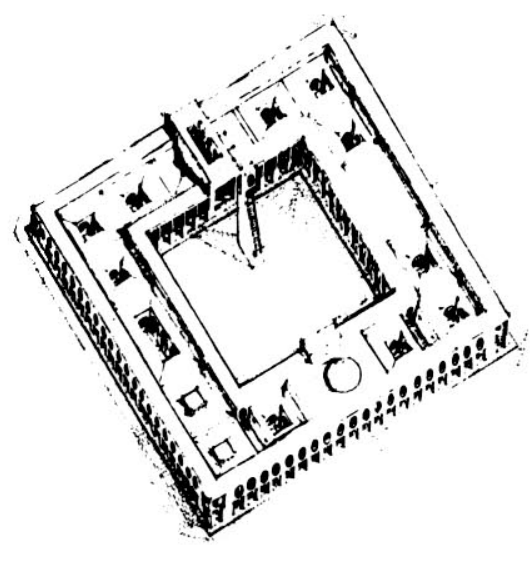

ANDREA PICCINI é professor do Departamento de Construção Civil da Escola Politécnica da USP. Durante cinco anos trabalhou como arquiteto e urbanista, na Argélia, para o Ministério de Obras Públicas e da Planificação, no programa VARA.
No quadro geral dos países em desenvolvimento a Argélia representa um fenômeno à parte e específico na importação e adoção de modelos arquitetônicos alheios ao próprio contexto sociocultural e físico-territorial, antes e depois, da sua independência. Este país seguiu um processo diferente dos outros países árabes; foi o primeiro, após a revolução, que na bacia do Mediterrâneo escolheu a via socialista para a própria reedificação.

A diferenciação no caso argelino é bem marcada tanto no período colonial como naquele pós-colonial; o marco da passagem entre as duas épocas foi uma sangrenta guerra de independência alcançada em 1962, que provocou a desintegração social de uma inteira geração e um milhão de mortos. Desde 1964, tornou-se um Estado socialista tendo como religião oficial a islâmica.

De fato, a França considerava este território como departamento francês além-mar e por isso, no momento da independência, a Argélia pagou e ainda está pagando um preço altíssimo a nível cultural e social como também em relação aos recursos humanos e econômicos. É só lembrar a falta de técnicos ainda hoje, trinta anos depois da libertação, como a falta de alguns recursos naturais importantes como as florestas, por exemplo, destruídas pelo exército francês com Napalm antes dos colonos se retirarem.

O modelo colonial imposto - cultural, social e econômico - teve um rebatimento através de representações espaciais tanto arquitetônicas quanto urbanas, tornando-as bases visíveis da expressão da estrutura socioeconômica de um poder colonial que investia massivamente neste território(1).

\section{A Herança: os Modelos da Cidade Colonial}

As estruturas urbanas das principais cidades-portos, como Argel e Oran, foram solidificadas no período colonial segundo um modelo econômico e territorial francês, desenvolvendo o papel de ligação entre o interior do país, agrícola, e a madre pátria, a França (Foto 1). Estas cidades assumiram, assim, a função de capitais periféricas, lugar de concentração de população européia, coração da administração colonial e, portanto, de irradiação de modelos de vida, que se refletiam na implantação de modelos arquite-
1 "Antes de tudo, o ato de morar é uma manifestaçăo de caráter cultural, $\theta$ enquanto as técnicas e os materiais variam com o progresso, o habitar um espaço além de manter vínculos com a modernidade também está relacio a modernidade também está cionais da sociedade". Carlos A. C. cionais da sociedade". Carlos A. C. a história), Săo Paulo, contexto, 1989.

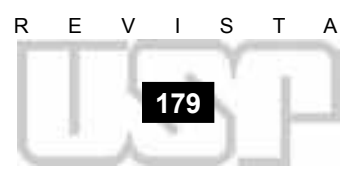


tônicos e urbanos.

Neste período, o modelo colonial produziu estruturas territoriais extremamente hierarquizadas constituídas de uma série de infra-estruturas e centros adensados ao longo da costa que convergiam para cidade-porto. Esta estruturação segue e, em outras vezes, se sobrepõe à organização urbana da cidade pré-colonial, a cidade islâmica, dita medina, transformando-a tanto nos seus modelos de vida quanto em suas formas arquitetônicas. Estas passam a depender das diferentes fases de penetração do capital francês, que provocou uma diferente valorização das terras intra-urbanas, através de novas construções impostas com os planos urbanísticos.

Houve também interferência nas zonas rurais, principalmente até a faixa do deserto saariano, com a implantação de uma cultura voltada à viticultura. Este sistema de produção transformou a vida não só do argelino sedentário, que sendo muçulmano não consumia vinho, mas também do argelino nômade. Os colonos franceses se apropriaram das terras mais férteis chamadas pelos árabes "de percurso", terras de uso, por exemplo, para a pastorícia, agricultura de subsistência e abastecimento local.

A visão originária de assentamento e do uso das terras foi, e se coloca, na base do choque entre as duas culturas, a colonial e a árabe-nômade. $\mathrm{O}$ uso tribal das terras, em geral, é ć́clico, por ser sua população nômade e é, também, coletivo e comunitário; se dá de forma regular mas diferente do uso fixo, contínuo e estável, de tipo ocidental. Este tipo de estrutura cultural e econômica de ocupação do território foi desconsiderado

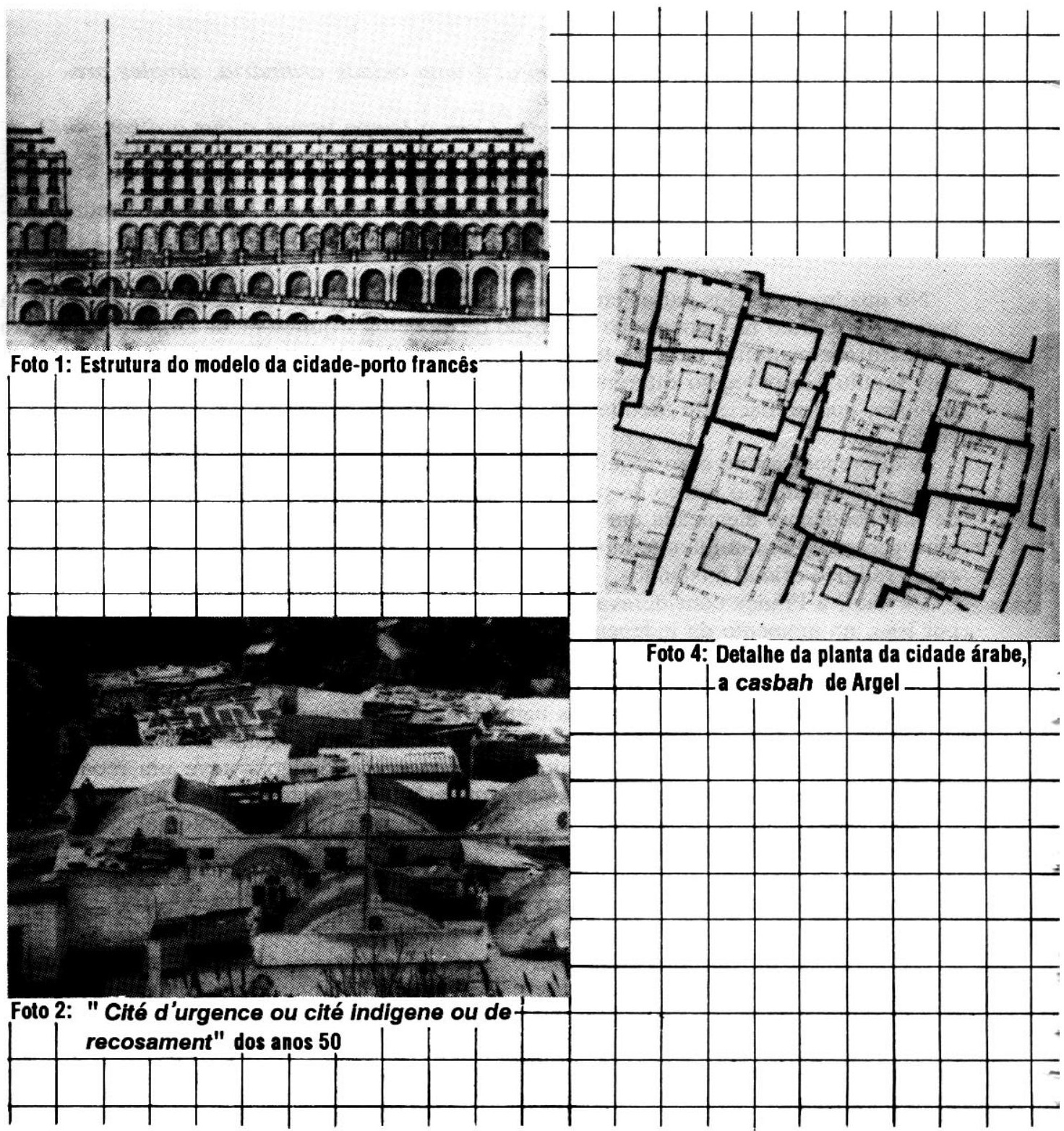


pelos colonizadores pois as terras eram vistas como não-habitadas, as chamadas "terras de ninguém", levando-os a ocupações de regiões inteiras ${ }^{(2)}$. As populações locais eram assim confinadas em terras menos férteis e inóspitas.

$\mathrm{Na}$ época colonial até os anos 20 as cidades apresentavam uma heterogeneidade da estrutura urbana resultante da sobreposição dos bairros de tipo europeu-ocidental aos bairros das cidades árabes, refletindo a coexistência de um setor capitalista dominante, dito dinâmico, em contraposição a setores chamados tradicionais e atrasados, a significar pré-coloniais. Estas cidades, como era o caso de Argel e Oran, foram desenvolvidas para abrigar o aparelho burocrático da colônia e as novas edificações, infra-estruturas e a mesma estrutura urbana foram remodeladas para abrigar os colonos, os administradores e a população européia criando um tipo de enclave na malha urbana ${ }^{(3)}$ em contraposição à "cidade antiga" ou "cidade tradicional", conhecida como casbah, habitada pelos árabes. Quando existiu a construção de novo hábitat para os árabes, este se localizava em zonas periféricas nas chamadas "cités d' urgence" (Foto 2). Estas eram constituídas por habitações unifamiliares e térreas, tendo no máximo dois cômodos e os serviços higiênicos, na maioria das vezes, externos e comunitários; situações estas, seguramente contrárias ao costume reservado árabe-muçulmano, baseado na divisão da habitação por sexo e idade.

Nas cidades coloniais a "madre pátria" sempre funciona como matriz, impondo códigos e modelos arquitetônicos e urbanos uniformizados procurando criar um marco da

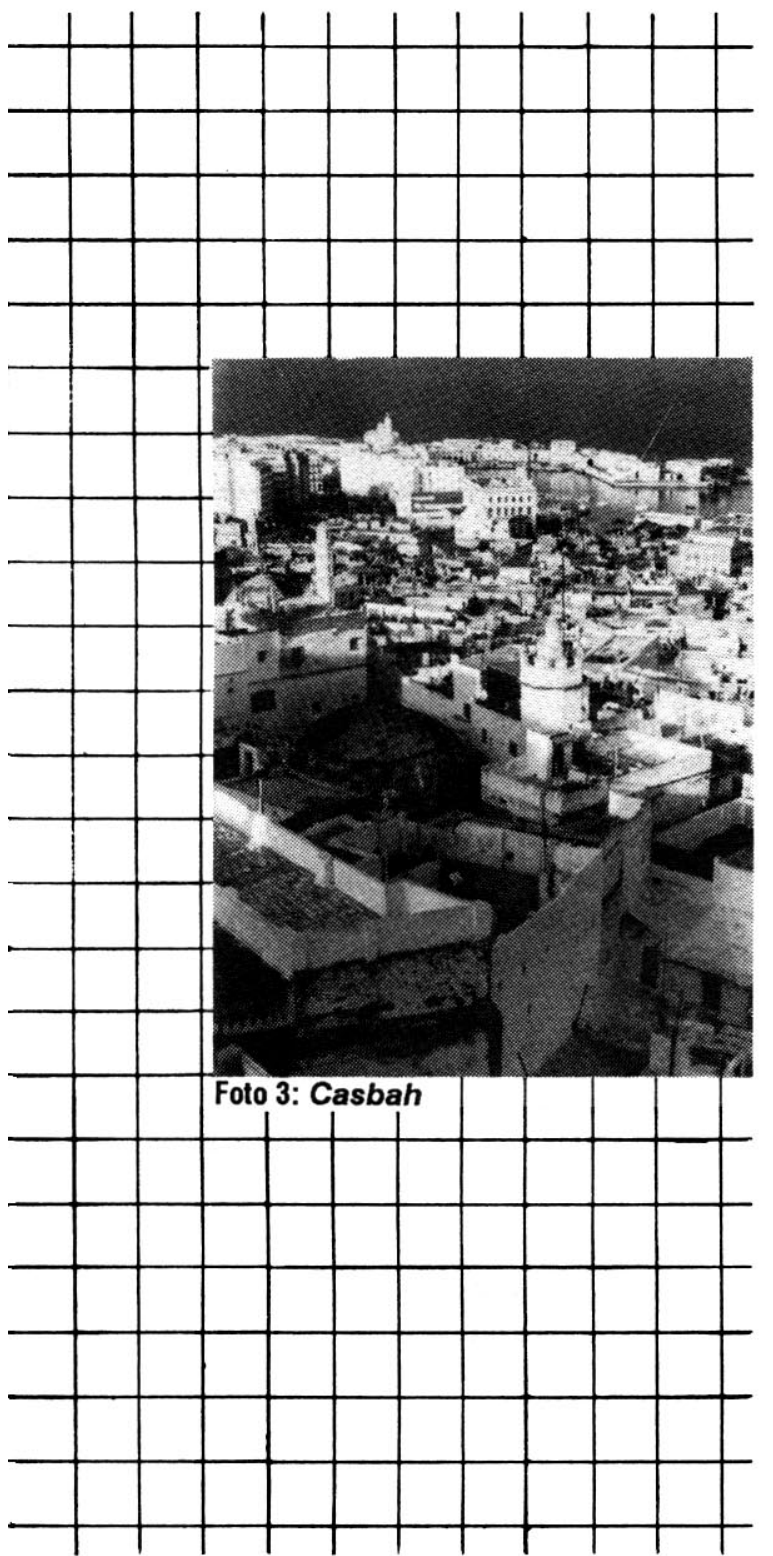
colonização na cidade: modernidade como símbolo de desenvolvimento. Muitas vezes estes modelos eram ligados às teorias ainda não aplicadas na prática e não experimentadas no país de origem, considerando, assim, a colônia como lugar justamente para experimentação.

Antes da chegada dos conceitos da arquitetura moderna, até 1930, a política urbana local consistia na intervenção pontual sem nenhuma estratégia global no contexto urbano, satisfazendo só a própria dinâmica do mercado imobiliário e dando sempre uma resposta demagógica às questões de maior importância político-social.

Apesar da introdução dos elementos da arquitetura moderna, a expansão da cidade de tipo europeu concentrava-se sobre questões de funcionalidade e racionalidade urbana, mas sempre submetida a conceitos de embelezamento da cidade, através de grandes edifícios de caráter público-administrativo, perspectivas monumentais, parques, etc., que denotavam a busca da dignidade "imperial". Sustentava-se, assim, o objetivo ideológico e econômico do poder que considerava Argel a capital da África do Norte, ao invés de se preocupar com a integração ao tecido urbano e habitacional local.

Nesta visão, a casbah habitada só por árabes era isolada e separada do resto da cidade, delimitada por grandes eixos monumentais e caracterizada como objeto exótico para turistas (Foto 3 e Foto 4).

$O$ traçado e implantação da cidade de tipo ocidental se colocava claramente em contraste com o contexto local, pois a cidade muçulmana nasce como resultado de um processo onde o espaço urbano reorganiza e transforma as primordiais solidariedades
2 Esta fôrmula jâ tinha sido usada na apropriaçăo das terras tribais por parte dos colonos e depois transforparte dos colonos e depois transtordo Sul. Mais tarde foi também readaptada e usada na formaçăo do Estado de Israel ("Série Documentos das Naciones Unidas", ONU).

3 A funçăo primária deste tipo de cidade era aquela de permitir o escoade era aquela de permitir o esco mento dos produtos agrícolas em direção da metrópole, Paris, e ao mesmo tempo permitir a penetraçáo nas colónias de produtos industrializados 


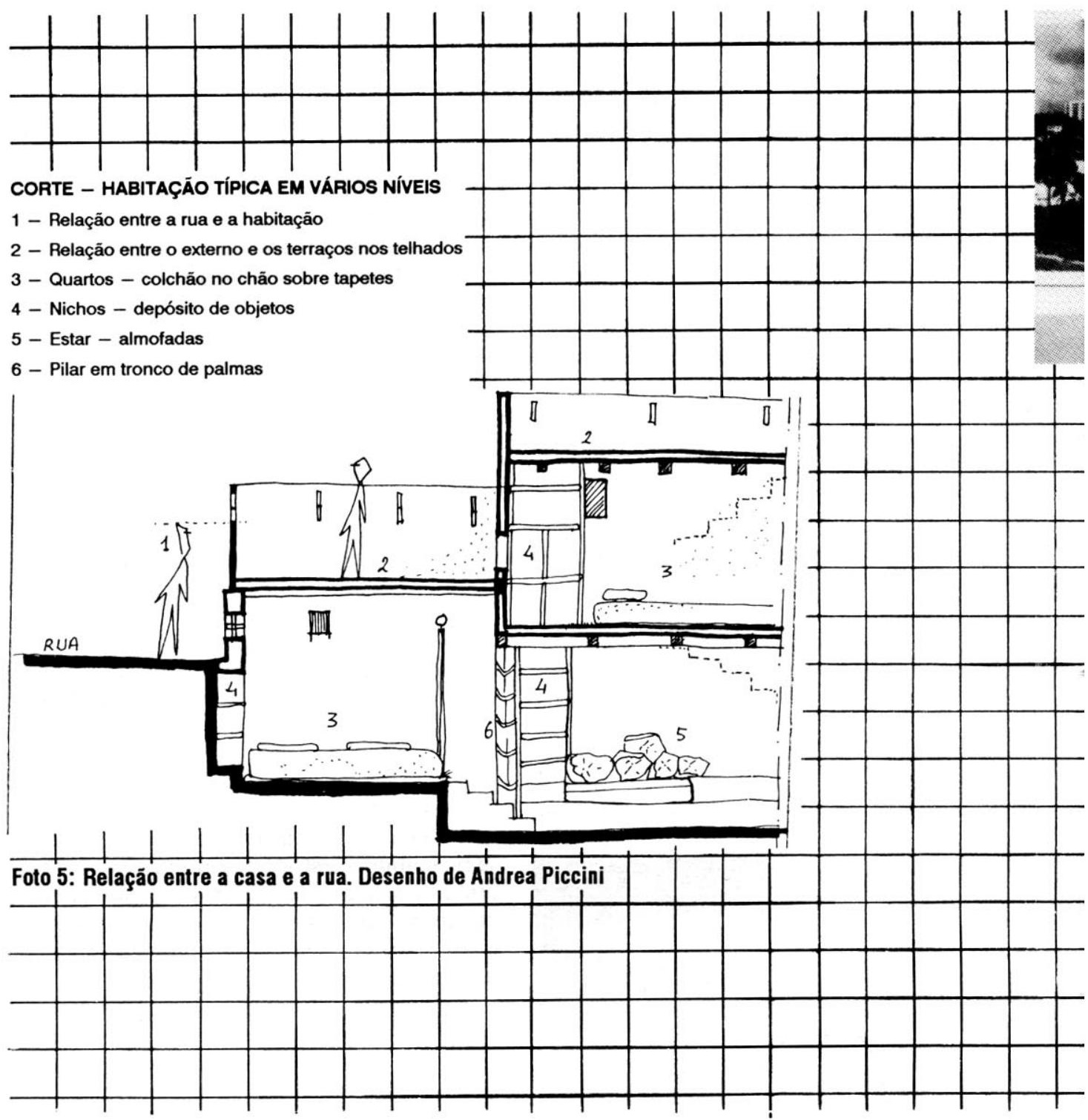

tribais em vínculos econômicos e sociais sob uma única orientação político-religiosa, que define um código único e uniforme.

Os elementos básicos de um assentamento urbano árabe-muçulmano são:

- a Mesquita, o Palácio e os mercados em volta destes, que compõem o centro principal da estrutura urbana, agrupando e centralizando as funções religiosas, políticas e econômicas;

- os bairros que circundam o centro são distribuídos segundo uma divisão clânica, tribal e dinástica (nome de famf́lia e sangue);

- total continuidade e uniformidade construtiva habitacional, sendo o traçado urbano formado por uma constante repetição de moradias organizadas com relação a uma malha externa de corredores estreitos e de vielas. Cada uma destas casas é uma propriedade que se organiza e se fecha em volta de um pátio interno facilitando a separação da familia dos desconhecidos ${ }^{(4)}$ (Foto 5).

No modelo da cidade colonial, com a parcial destruição da casbah, a população árabe foi sendo empurrada a construir em zonas cada vez mais difíceis topograficamente, nas colinas periféricas, em meias-encostas, sendo os terrenos planos preservados para a cidade residencial européia e para as zonas militares. Os assentamentos precários, as bidonvilles, assumiram dimensōes sempre mais visíveis do caráter segregante da organização urbana colonial mesmo com a construção das "cités d' urgence".

Paralelamente, em alguns novos bairros europeus foram formados os "grandes en-

4 Andrea Piccini, "Ghardaia, uma fortaleza no deserto", in Revista Projeto n 90, Săo Paulo, agosto/1986. sambles", edifícios destinados a resolver o problema habitacional da população euro- 


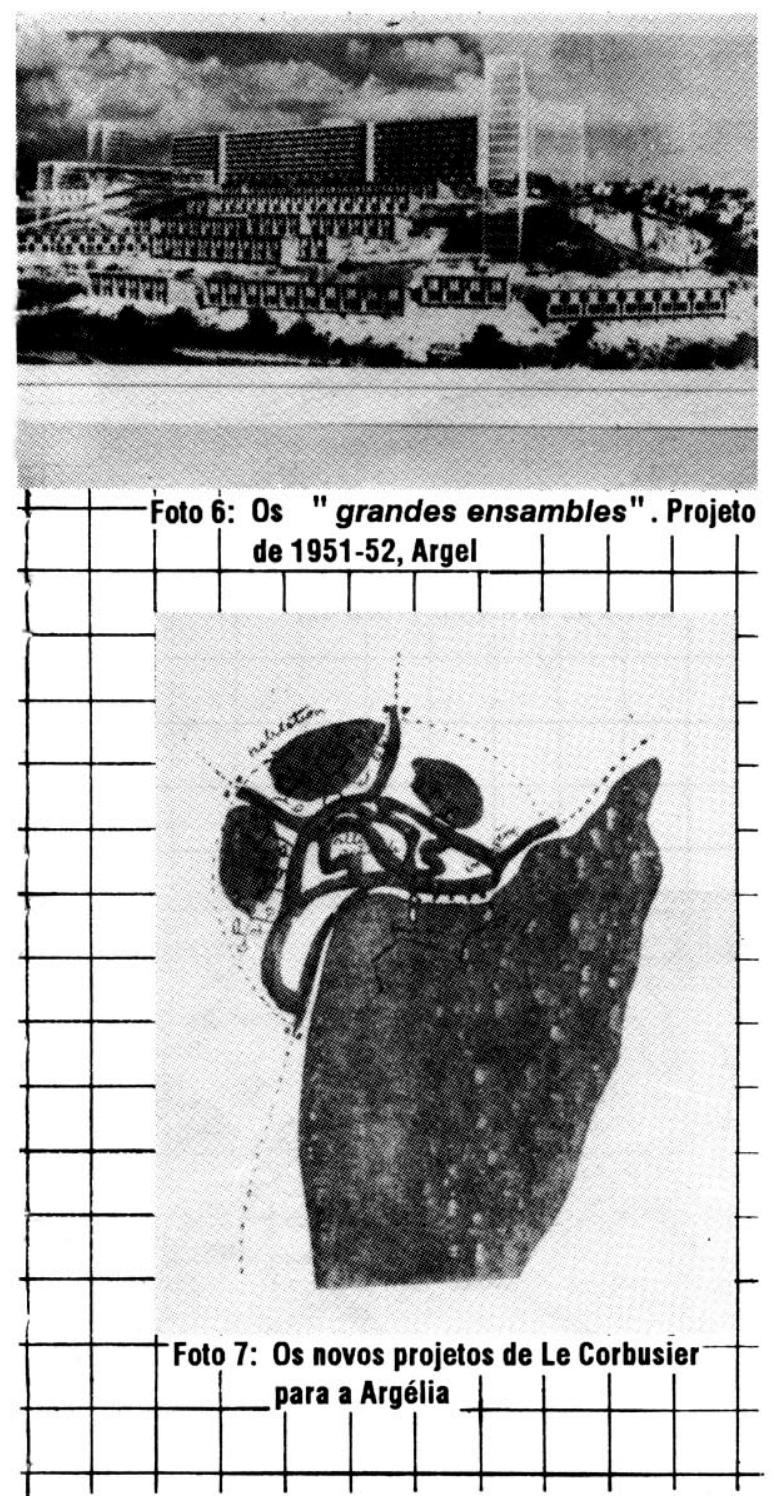

péia de baixa renda e os "aero-habitat", construções de mais de dez andares, visíveis ainda hoje no centro de Argel e Oran, destinadas à residência da classe média (Foto 6). Estes novos projetos eram também uma resposta imediata à questão da ocupação da mão-de-obra local e um importante canal de penetração do capital francês junto aos interesses da burguesia muçulmana.

Com este tipo de intervenção a França deixava um marco geral uniformizado nas capitais das próprias colônias tornando-as capitais internacionais do império com características similares, independentemente do contexto histórico e sociocultural, como foi o caso de Argel, Tunis, Casablanca, Dakar e Adbijan.

A uniformização se dá através da introdução e do uso da arquitetura moderna com a imposição de modelos e de símbolos, de forma forte e marcante, para destacar o progresso e justificar as novas regras socioculturais sobre a população árabe, "subdesenvolvida e incapaz de desenvolver-se".

A partir de 1930, as novas idéias do binômio "arquitetura-sociedade moderna" chegavam a Argélia veiculadas por Le Corbusier que aplicava as teorias como num grande laboratório experimental. Entre os vários planos urbanísticos de Argel, aquele por ele estudado, de 1942, marcava uma passagem importante no desenvolvimento urbano desta cidade, porque não destruía ou tombava a cidade árabe, como acontecia anteriormente com a política urbana francesa. Este novo plano considerava e admitia a existência de duas cidades dentro da mesma estrutura urbana - a árabe e a européia -, confirmando assim, através da política urbanística, a segregação da política colonial.

Segundo a visão de Le Corbusier, na área central da cidade européia são planejados os centros comerciais e de atividades terciárias ("cité d'affaires"). Circundando-os, à meia-encosta, nas colinas, frente ao grande porto, mergulhadas na natureza, estão colocadas as tipologias habitacionais que antecipam as "unite d' habitation". Ligando a área residencial ao centro, são projetadas construções contínuas de serviços. Nas partes mais altas das colinas e atrás destas, são planejadas as "cité d" urgence", os bairros novos para a população árabe-muçulmana.

O novo plano legitimava de fato o processo de marginalização cultural, social e econômica em que se encontrava a população da cidade árabe através do chamado "plano de revitalização do assentamento árabe", mostrando assim as contradições especificas da cidade colonial moderna, as diferenças entre o assentamento europeu e aquele local onde a cidade dos affaires era planejada em conjunto com a cidade européia e as instituições árabe-islâmicas com a casbah (Foto 7, Foto 8 e Foto 9).

Em resumo, os principais modelos e planos urbanísticos implantados no período colonial foram:

- o urbanismo militar, entre $1830-80$, assim chamado por praticar grandes cortes nas cidades árabes tradicionais, as medinas, justificando-se por razões defensivas com relação a uma estabilidade político-militar de conquista a curto prazo;

- o urbanismo de "Beaux Artes", até 1890 - planos urbanísticos desenvolvidos pela escola francesa de Belas Artes;

- o urbanismo de alinhamento, até 1930, com o qual se operavam cortes estruturais na 
cidade para revigorar o novo contexto urbano de forma triunfal e imperial, através de amplas e longas alamedas, tendo ao longo do percurso habitações de alto padrão e edifícios administrativos de prestígio, seguindo por quilômetros um rigoroso alinhamento, com claras influências haussmanianas (Foto 10);

- o urbanismo-arquitetura moderna, com Le Corbusier, até a independência em 1962.

\section{A INDEPENDÊNCIA: NOVOS MODELOS}

A nova constituição argelina pós-independência, em seu primeiro artigo, define que "a Argélia é uma nação e a nação não é um conjunto de povos ou um mosaico de etnias dispersas". Em contraste com essa afirmação, existem na realidade presenças culturais e econômicas diferentes tanto no âmbito regional como no nacional. A população é predominantemente árabe, porém, com marcante presença de grupos culturais distintos como os Kabilias ao norte, os Mozabitas ao centro e os Tuaregues ao sul do país. A sociedade apresenta-se de fato constituída por diversas etnias estruturadas em tribos, clãs e famílias, sendo portanto a relação de parentesco, fictícia ou real, o elemento unificador de sua organização. Esta estrutura tribal reemergente no período pós-colonial, afluindo algumas vezes em movimentos regionalistas, apresenta-se em antítese com os pressupostos fundamentais do programa de reunificação nacional lançado após a independência.

De outro lado, o componente religioso foi e é um elemento catalisador, que no período revolucionário, com base na fé que prenunciava o nacionalismo, agrupava e agrupa todas as camadas da sociedade argelina, independentemente das relações internas entre clãs e tribos. Frente a esta situação o principal programa após a independência foi a procura de equilíbrio entre cidade e zona rural, com a introdução de planejamento territorial local, regional e nacional a curto, médio e longo prazo, contrariamente ao período anterior quando as preocupações com o planejamento se relacionavam só às grandes cidades.

Em 1965, o governo argelino lançou o programa que viria a se constituir na espinha dorsal da independência: os VARAS (Bairros Socialistas da Revolução Agrária). Estes eram divididos em três tipologias segundo os tipos de serviços que ofereciam e a população atendida. Foram planejados com os objetivos principais de: bloquear as grandes migrações pós-bélicas vindas do interior agrícola em direção aos novos pólos industriais e petrolíferos; intervir no nomadismo tradicional bloqueando-o; ser um importante suporte das novas relações econômicas cooperativistas de produção na agricultura.

Os projetos deveriam representar uma concepção urbana nova, como símbolo da conquistada nova união nacional e, em particular no mundo rural, expressão do socialismo cooperativista em substituição à bandeira religiosa ${ }^{(5)}$. Em geral, porém, tanto os projetos urbanísticos quanto os arquitetônicos significaram na maioria das vezes o resultado de ações de prestígio político com fins propagandísticos. $\mathrm{O}$ marco urbanístico e arquitetônico da independência foi influenciado por modelos importados ainda de tom "prestigioso-monumental" readaptados sempre com símbolos e elementos arquitetôni- 
ferentes nações que colaboravam para a "modernização" das estruturas do país. Vale lembrar, por exemplo, a estrutura de saúde, sustentada por cooperantes chineses, franceses e de vários países do Leste europeu; aquela da educação se apoiava em cooperantes franceses nos ciclos básicos e italianos nas universidades; no campo da gestão urbana e da construção civil, por franceses, italianos e de países do Leste europeu que também colaboravam na estrutura administrativa municipal e estadual; no campo das telecomunicações encontravam-se japoneses e, enfim, toda a indústria petrolífera era mantida com a colaboração de técnicos americanos e alemães.

\section{A NOVA INDEPENDÊNCIA}

O rumo da atual situação sociopolítico-religiosa que vem se desenvolvendo na Argélia com a avanço dos fundamentalistas muçulmanos nas últimas eleições municipais, representa um refluxo às posições mais tradicionalistas pois se apóia em uma unificação político-religiosa frente a perigos externos, exatamente como no período da revolução.

O descontentamento pelo baixo nível econômico alcançado pela população depois de trinta anos de colaboração internacional canalizou-se no pretexto da desculturalização das tradições. De fato, os modelos importados pelos cooperantes com relação à saúde, à educação e ao planejamento em geral da vida moderna argelina, mais viś́vel no marco arquitetônico e urbano, de um lado ajudaram a levar o país a um outro patamar de inserção econômica no contexto mundial mas, por outro, se chocavam com as diferentes manifestações culturais tradicionais da estrutura social-religiosa.

Esta intromissão forçada e maciça da vida moderna só era aceita pela população em função de um desenvolvimento econômico equilibrado que respeitasse também as culturas locais. Quando se percebeu que o alcance do bem-estar social interno não seria estendido a todos, que o programa para participar da economia mundial não poderia ser respeitado e que o preço deste era a desintegração da própria estrutura sociocultural, recomeçaram a vigorar os laços estreitos entre árabes e muçulmanos através do fator religioso que, junto com a língua, sempre se constituiu em elemento histórico unificante das várias populações e países desde a origem do Islã. A vitória dos fundamentalistas e a decisão de arabização imediata da vida argelina levará a uma transformação substancial em relação aos modelos ocidentais até agora implantados no país, instaurando novas relações com o ocidente via cooperação internacional.

Este tipo de relações complexas as encontramos também em outros países árabes do Magreb, como a Tunísia, o Marrocos e também o Egito, os quais sendo paŕses cujo processo de independência foi historicamente diferenciado leva-os, hoje, a uma situação conjuntural diferente. Estes países considerados "mais abertos" aos estrangeiros apresentam uma convivência mais tranqüila com o mundo ocidental sobretudo com os países da bacia do Mediterrâneo e onde o convívio entre as duas culturas, ocidental e árabe, se dá de forma mais harmônica através da alta burguesia local comprometida e identificada com interesses es-
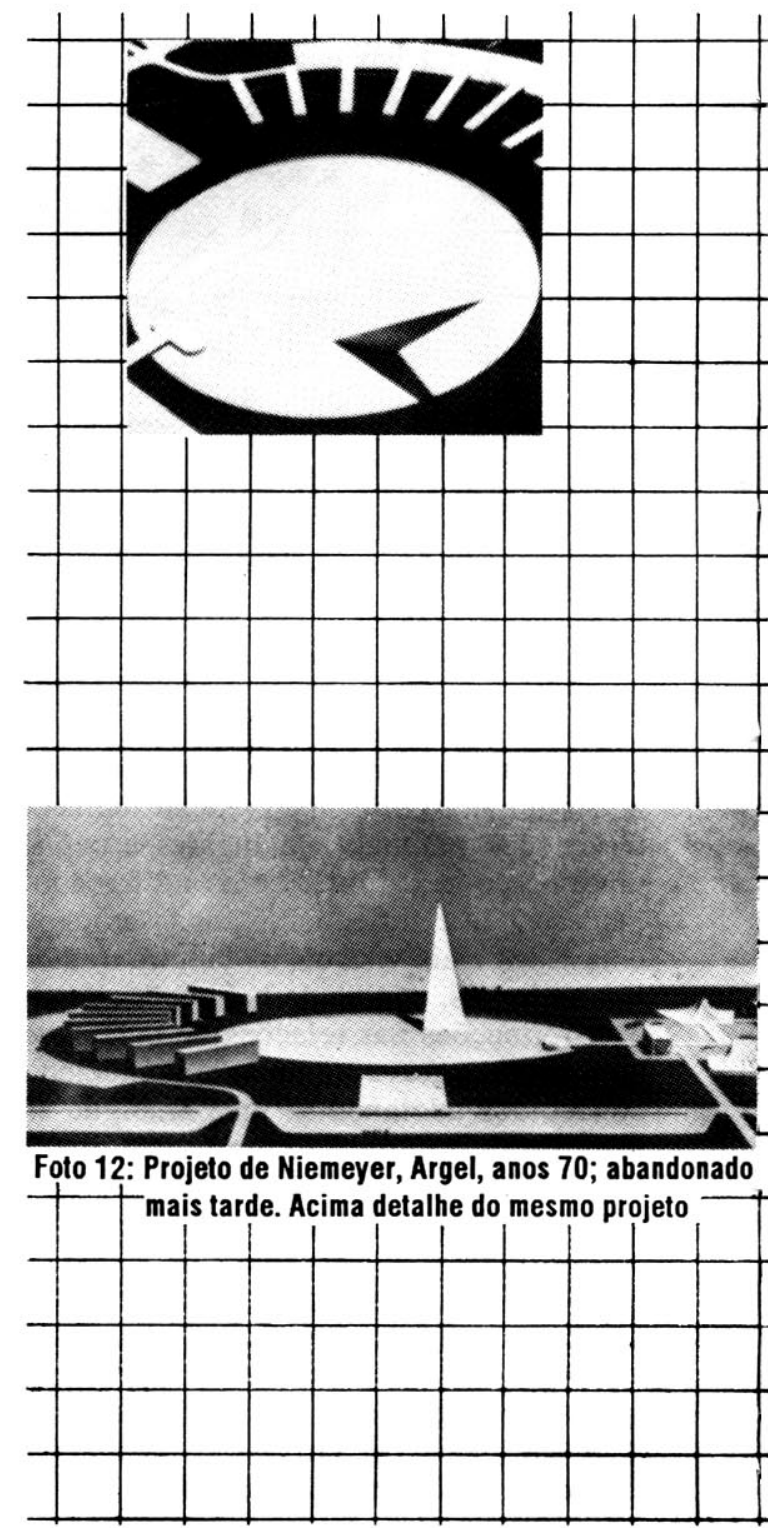
trangeiros. Vale lembrar que as palavras "fechado" e "aberto", usualmente utilizadas, procedem em parte de uma visão ocidental para classificar estes países segundo um suposto grau de aceitação dos costumes ocidentais. O que deveria ser exatamente o contrário, e é o que todas as entidades árabes reivindicam, isto $\epsilon$, um maior esforço na procura de um equilíbrio e na aceitação por parte do mundo ocidental da complexidade da cultura árabe-muçulmana, não mais analisada através de uma rígida e racional lógica cartesiana européia. Este atávico conflito que se arrasta desde a época das cruzadas parece não ter encontrado soluções até hoje.

As potências ocidentais intervieram em várias épocas e de diversos modos e formas, oferecendo ate "proteção", sobretudo no Oriente Médio, colocando-se assim numa região onde ainda não estavam resolvidos os conflitos internos culturais, políticos e religiosos entre os componentes do próprio mundo árabe. Conflitos estes interrompidos e reativados ao longo dos anos, desde a desagregação do império árabe-muçulmano, como por exemplo após a queda do império turco e com o fim dos protetorados ingleses e franceses que perduraram em alguns casos até depois da Segunda Guerra Mundial.

O processo de estruturação territorial de muitos países árabes foi decidido sempre no exterior, com divisões forçadas de países e nascimento de outros, inventados pelas potências ocidentais segundo a própria lógica e interesse. De fato, foram criados depois da Primeira e Segunda Guerra Mundial o Líbano, Jordânia, Israel, Kwait, Iêmen do Norte e Iêmen do Sul e outros países, interferindo drasticamente na estruturação da península

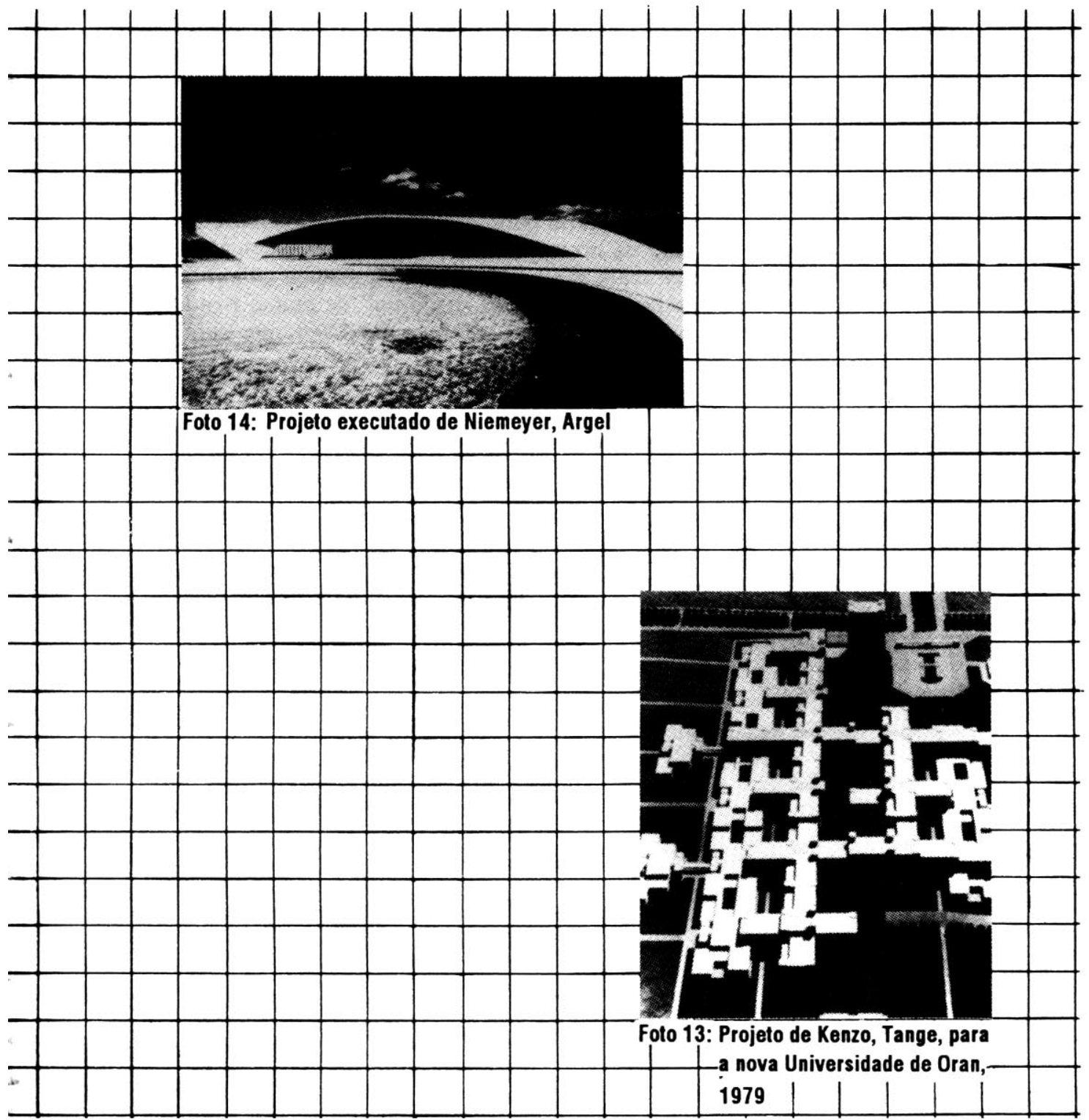


Arábica e Oriente Médio, além das intervenções pontuais nesta região, ao longo dos anos, desde aquela no Canal de Suez contra a sua nacionalização por parte de Nasser, ou a entrada das forças multinacionais no Lfbano.

Todas estas subdivisões não consideravam a presença do importantíssimo elemento étnico e tribal e das relações antropológicas e socioculturais das diferentes populações existentes no local - curdos, armênios, sírios, palestinos, drusos, maronitads, etc. - que foram separados de forma culturalmente aleatória, porém estrategicamente interessante para o ocidente.

A estrutura social tribal das comunidades permite uma acirrada disputa interna pelo poder e, no momento oportuno, a união das forças contra um perigo externo. Um exemplo é o caso do Ĺbano, criado pelas potências ocidentais sobre delicados equilibrios sociopolíticos-religiosos. Por causa do aglomerado de diferentes entidades árabes em conflito pelo controle de interesses locais, nunca surgiu um poder que conseguisse ter sob controle as diferentes guerras internas, sendo sempre externas as soluções ao contexto sociocultural da região.

\section{Perspectivas}

A recente guerra na região do golfo abrirá grandes e novas possibilidades para o mercado internacional em todos os níveis, para reconstrução dos países beligerantes. Visto que estes países foram quase totalmente destruídos, supõe-se que se apresentará uma rara ocasião no próximo decênio para reaquecer o mercado da construção em nível mundial, pois de fato já foi aberta a corrida entre as grandes potências para ganhar o maior número de contratos de construção.

Apresenta-se, assim, uma ocasião única, uma experiência atual e futura a ser seguida, pesquisada e estudada enquanto mudanças no comportamento sociocultural das populações que receberão ajuda, mudanças que já estão em embrião, por exemplo, na Arábia Saudita.

Em vista das experiências relatadas é natural perguntar-se qual será o marco da nova colaboração internacional, quais serão os novos modelos e as novas técnicas de construção: será numa linha arquitetônica mais high-tech com uma maciça colaboração japonesa e/ou americana, ou será uma linha árabe "pós-moderna" de cunho pendente ao estilo do império inglês ou francês nostálgicos pós-Laurence? É só agüentar para ver.

\section{BIBLIOGRAFIA}

AGERON, Charles-Robert. Histoire de l Algérie contemporaine (1830-1973). Paris, Ed. Presses Universitaires de France, 1974.

CAMUS, Albert. La peste. Paris, Ed. Gallimard, 1947.

LE CORBUSIER. Maniere de penser l urbanisme. Paris, Ed. Gonthier, 1963.

SVILUPPO, Revista trimestrale di Formazione, Economia e Cooperazioni, Magreb no 4-5, Milano, Ed. Franco Angeli, 1980.

TECHNIQUE e ARCHITETURE, L'Algérie no 329. Paris, fev.-mar./1980. 